\title{
PERANCANGAN ENTERPRISE ARCHITECTURE PADA FUNGSI REKAM MEDIS RUMAH SAKIT DENGAN PENDEKATAN TOGAF ADM
}

\section{ENTERPRISE ARCHITECTURE DESIGN OF HOSPITAL MEDICAL RECORDS FUNCTION USING TOGAF ADM}

\author{
Sukrina Herman ${ }^{1}$, Asti Amalia Nur Fajrillah ${ }^{2}$, Rachmadita Andreswari ${ }^{3}$ \\ 1,2,3 Program Studi Sistem Informasi, Fakultas Rekayasa Industri, Universitas Telkom \\ ${ }^{1}$ sukrinahermanheral01@gmail.com, ${ }^{2}$ astiamalia@telkomuniversity.ac.id, ${ }^{3}$ andreswari@gmail.com
}

\begin{abstract}
Abstrak - Dengan semakin meningkatnya kebutuhan aplikasi pada rumah sakit guna menunjang kinerja pada setiap unit, semakin banyak pula ragam dan jumlah aplikasi yang dibangun. Namun pembangunan aplikasi tersebut tidak diiringi dengan perencanaan yang matang, sehingga seringkali pembangunan aplikasi tidak saling terintegrasi. Hal ini menyebabkan pemanfaatan dari aplikasi itu sendiri belum maksimal. Guna memaksimalkan pemnfaatan dari aplikasi itu sendiri, salah satunya dapat diupayakan melalui perancangan enterprise arsitektur, yang mampu membantu untuk menyelaraskan kebutuhan bisnis dengan berbagai aplikasi yang merupakan layanan pendukung proses bisnis. Oleh Karena itu dalam penelitian ini akan membahas perancangan Enterprise Architecture pada fungsi Rekam Medis Rumah Sakit dengan pendekatan TOGAF ADM. Enterprise Architecture merupakan gambaran bisnis, data, aplikasi dan teknologi dalam pengembangan sebuah atau sekumpulan system. Dalam perancangan Enterprise Architecture ini menggunakan TOGAF ADM (architecture Development methode) dengan tahapan Preliminary phase, Architecture Vision, Business Architecture, Information System Architecture, Technology Architecture, Opportunities And Solutions dan Migration Planning. Hasil akhir pada kajian ini berupa usulan architecture model pada fungsi Rekam Medis Rumah Sakit dan business value assessment yang berfungsi sebagai acuan dalam pembangunan Sistem Informasi (SI). Salah satu hasil dari analisis terhadap architecture model yang dihasilkan berupa I-HOSST (Integrated Hospital Information System), yang merupakan aplikasi terintegrasi guna menunjang kinerja fungsi Rekam Medis serta fungsi lain yang berkaitan pada rumah sakit.
\end{abstract}

Kata kunci: Rekam Medis, Enterprise architecture, Rumah Sakit, TOGAF.

\footnotetext{
Abstract - With the increasing needs of applications in hospitals to support the performance of each unit, the more variety and number of applications built. But the development of the application is not accompanied by careful planning, so often the application development is not mutually integrated. This causes the utilization of the application itself is not maximized. To maximize the utilization of the application itself, one can be pursued through the design of enterprise architecture, which is able to help to align business needs with various applications that are business process support services. Therefore in this research will discuss the design of Enterprise Architecture on Hospital Record Medical function with TOGAF ADM approach.
}

Enterprise Architecture is an overview of business, data, applications and technology in the development of an or a set of systems. In the design of Enterprise Architecture is using TOGAF ADM (architecture Development methode) with Preliminary phase stages, Architecture Vision, Business Architecture, Information Systems Architecture, Technology Architecture, Opportunities And Solutions and Migration Planning. The final result of this study is the proposed architecture model on Hospital Medical Record function and business value assessment that serves as a reference in the development of Information System (SI). One of the results of the analysis on the architecture of the model is I-HOSST (Integrated Hospital Information System), which is an integrated application to support the performance of Medical Record function and other related functions in the hospital.

Keywords: Medical Record, Enterprise architecture, Hospital, TOGAF.

\section{PENDAHULUAN}

Kemjuan teknologi berkembang begitu pesat pada beberapa tahun belakangan, salah satunya yaitu perkembangan sistem informasi (SI) sebagai penunjang kegiatan operasional diperusahaan ataupun instansi, tidak terkecuali rumah sakit sebagai layanan publik. Dampak perkembangan sistem informasi ini memunculkan pengembangan berbagai aplikasi, guna mengotimisasi aktivitas opersional dan membantu perusahaan dalam mengintegrasikan antara bagian manajemen dan operasional, dengan meningkatkan kualiatas pelayanan [1]. Namun seringkali banyaknya pengembangan aplikasi tersebut tidak diiringi dengan perencanaan yang matang, sehingga aspek interoperabilitas seringkali terkesampingkan. Hal ini menyebabkan sejumlah besar kegagalan dalam implementasi sistem informasi di rumah sakit salah satunya tidak digunakannya aplikasi yang sudah dibangun, disebabkan oleh ketidaksesuaian fungsi dengan kebutuhan bisnis [2].

EA (enterprise architecture) adalah pendekatan manajemen yang meanawarkan peningkatan performance perusahaan di segala bidang [3]. Selain membantu menajemen dalam mengindetifikasi strategi goal secara jelas, EA juga menyediakan informasi yang dibutuhkan sehingga memungkinkan keselarasan antara teknologi dan bisnis [4]. Belakangan ini banyak perusahaan yang menyadari pentingya mengadopsi konsep EA dengan tujuan: integrasi, 
penggunaan kembali aplikasi yang sudah ada, pengurangan resiko, dukungan keputusan, dan penyelarasan strategi bisnis [3], tidak terkecuali Rumah Sakit sebagai salah satu layanan publik dengan tingkat kompleksitas bisnis yang tinggi seperti pada fungsi Rekam Medis. Fungsi Rekam Medis merupakan catatan dan dokumen yang berisi identitas pasien, hasil pemeriksaan, pengobatan yang telah diberikan, serta tindakan dan pelayanan lain yang diberikan kepada pasien yang dapat dipertanggung jawabkan [5].

Sebagai salah satu fungsi dengan kompleksitas yang tinggi, karna berkaitan dengan fungsi - fungsi lainnya pada rumah sakit, fungsi rekam medis merupakan fungsi dengan resiko yang tinggi. Kesalahan input ataupun duplikasi data berdampak pada catatan rekam medis pasien sehingga memunculkan kemungkinan kesalahan dalam diagnosis (pangambilan keputusan) pada pasien. Selain itu belum optimalnya keterhubungan antar fungsi dapat mempengaruhi response time dalam pertukaran informasi antar fungsi sehingga berakibat pada kepuasan pasien. Untuk mengatasi hal tersebut, diperlukan sebuah rancangan EA bagi fungsi Rekam Medis di rumah sakit.

Hasil akhir dari kajian ini berupa arsitektur model pada fungsi Rekam Medis di rumah sakit yang meliputi bisnis, data, aplikasi dan teknologi berserta business value assesment yang berfungsi sebagai acuan dalam pembangunan Sistem Informasi (SI).

\section{STUDILITERATUR}

Enterprise architecture diperkenalkan pada tahun 1980an yang bermula dari permasalahan yang terjadi pada arsitektur sistem. Permasalahan yang terjadi mengenal ruang lingkup yang didesain dan tingkat kompleksitas pada implementasi sistem informasi yang meningkat dan meluas, sehingga dibutuhkan sebuah logika (arsitektur) yang dapat mengendalikan dan mendefinisikan interface dengan mengintegrasikan semua komponen dalam sistem tersebut [6]. Enterprise Architecture merupakan gambaran dari visi misi stakeholder baik itu berupa informasi, fungsionalitas/ kegunaan, lokasi organisasi dan ukuran kinerja yang bertujuan untuk mengembangkan sebuah sistem atau sekumpulan system [7]. EA merupakan metode yang digunakan untuk merancang dan mewujudkna struktur, proses bisnis, system informasi dan infrastruktur organisasi [8].

Keuntungan dalam menggunakan EA bagi perusahaan diantaranya yaitu:

a. Operasi bisnis yang lebih efisien

- Rendahnya biaya operasi binis,

- Biaya managemen perubahan lebih rendah,

- Tenaga kerja lebih fleksibel

- Peningkatan bisnis lebih produktifitas

b. Lebih efisiennya operasi IT

- Rendahnya biaya pengembangan perangkat lunak

- Mudahnya melakukan upgrade dan pertukaran komponen sistem

- Dan peningktan portabilitas aplikasi [8].

Berdasarkan tabel I dijelaskan perbandingan karakteristik Enterprise Architecture Framework yang dapat dilihat pada Tabel I dibawah ini [2].
TABEL I

PERBANDINGAN EA FRAMEWORK

\begin{tabular}{|c|c|c|}
\hline \multirow{2}{*}{$\begin{array}{c}\text { New Criteria } \\
\text { Business Process }\end{array}$} & Framework & Score \\
\hline \multirow{4}{*}{ Readiness Assessment } & Zachman & 1 \\
\cline { 2 - 3 } & TOGAF & 1 \\
\cline { 2 - 3 } & FEA & 1 \\
\cline { 2 - 3 } & Gartner & 1 \\
\hline \multirow{3}{*}{ Zachman } & 1 \\
\cline { 2 - 3 } & TOGAF & 4 \\
\cline { 2 - 3 } & FEA & 2 \\
\cline { 2 - 3 } & Gartner & 3 \\
\hline
\end{tabular}

Legenda:

$1=$ Tidak sesuai dengan jenis pekerjaan

2 = Kurang sesuai dengan jenis pekerjaan

$3=$ Pekerjaan sesuai dengan framework

4 = Framework sangat sesuai dengan jenis pekerjaan

Jadi, berdasarkan tabel I dapat simpulkan dari kriteria business process standarization bahwa semua framework memerlukan proses yang baru untuk membakukan proses bisnis, sedangkan dari segi readiness assessment (penilaian kesiapan) bahwa Togaf lebih menyediakan pendekatan yang terbaik untuk menilai kesiapan [2]. Berdasarkan hasil perbandingan EA Framework pada tabel I diatas, maka dalam penelitian ini menggukanan perancangan Enterprise Architecture pada fungsi Rekam Medis di Rumah Sakit menggunakan TOGAF ADM.

The Open Group Architectural Framework atau biasa disebut TOGAF merupakan kerangka kerja (framework) yang menjelaskan aturan untuk mengembangkan prinsip-prsinsip arsitektur perusahaan dengan menggunakan tools dan metode yang detail untuk mengimplementasikannya [9]. Secara lengkap TOGAF ADM terdiri dari 8 fase yaitu:

a. The preliminary phase menggambarkan tahapan dalam proses perancangan dengan melakukan penyusunan suatu framework dalam bentuk visi architecture dan juga prinsip prinsip architecture berupa proses bisnis, data aplikasi dan teknologi.

b. Phase A: Architetcure Vision menjelaskan fase awal siklus pengembangan arsitektur yang berisikan gambaran batasan-batasan dari rancangan arsitektur dengan menjelaskan scope, batas-batasan dari rancangan arsitektur, dengan menetapkan visi arsitektur yang diusulkan.

c. Phase B: Business Architecture menjelaskan perkembangan arsitektur bisnis untuk mendukung visi arsitektur yang disepakati.

d. Phase C: Information System Architecture menjelaskan bagaimana pengembangan arsitektur sistem informasi, dengan lebih menenkankan pada kebutuhan suatu aplikasi yang sudah direncanakan untuk mendukung visi arsitektur.

e. Phase D: Technology Architetcure, menggambarkan tentang teknologi yang akan dibangun, pada suatu proyek dengan menentukan terlebih dahulu kandidat - kandidat teknologi untuk mendukung visi arsitektur yang disepakati.

f. Phase E: Opportunity \& Solution, pada tahap ini lebih menekankan pada perencanaan implementasi awal, meliputi architecture bisnis, data, aplikasi dan teknologi yang dijelaskan pada fase sebelumnya. 
g. Phase F: Migration Planning, melakukan penilaian dari rencana migrasi dan rencana implementasi dari suatu SI.

h. Phase G: Implementation Governance, menyediakan pengelolaan suatu arsitektur terhadap implementasi, meliputi pengelolaan organisasi, sistem informasi dan arsitektur dengan tujuan untuk merumuskan rekomendasi dari setiap proyek yang diimplementasikan.

i. Phase H: Architetcure Change Management, mencakup penyusunan dan membuat prosedur untuk mengelolah perubahan ke arsitektur yang baru, dengan tujuan untuk menetapkan proses manajemen perubahan.

j. Requirement Management, mendefinisikan kebutuhan yang diperlukan untuk siklus / fase pada TOGAF ADM [9].

Untuk membangun perancangan EA, pada framework TOGAF terdapat 4 domain arsitekur, di antaranya:

a. Arsitektur Bisnis mendefinisikan strategi bisnis, pemerintahan, organisasi, dan proses bisnis utama.

b. Arsitektur Data yang menjelaskan struktur organisasi data logis dan fisik aset serta data yang berkaitan dengan pengelolaan data sumber daya perusahaan.

c. Arsitektur aplikasi menyediakan cetak biru untuk aplikasi individu untuk digunakan, interaksi dan hubungan antara sistem aplikasi serta hubungan dengan proses bisnis inti organisasi.

d. Arsitektur teknologi yang menggambarkan kemampuan dari suatu software dan hardware yang dapat menunjang pembangunan suatu layanan bisnis, data dan aplikasi, termasuk IT infrastruktur, middleware, jaringan, komunikasi, pengolahan, standard [9].

\section{METODOLOGI PENELITIAN}

Metodelogi pada kajian ini mengadopsi TOGAF ADM dmanan dibagi menjadai 3 bagian yaitu input, process, dan output. Model konseptual merupakan suatu gambaran umum dalam melaksanakan penelitian yang memiliki 3 elemen yaitu input, prosess dan output. Dalam kajian ini input terkait dengan rencana strategi perusahaan yang digunakan sebagai panduan kebutuhan yang dibutuhkan oleh organisasi, profil (visi dan misi) Rumah Sakit sebagai acuan dalam pemenuhan tujuan bisnis, IT Masterplan perusahaan dan dokumen pengembangan bisnis dan kondisi eksisting untuk mengidentifikasi masalah yang terkait pada proses bisnis dan IT yang sedang berjalan pada rumah sakit, SOP dan strategic planning yang ada pada rumah sakit. Pada kondisi eksisting terdapat people, proses, dan technology technology yang merupakan stakeholder dan ruang lingkup pada area rumah sakit.

Dalam kajian proses yang merupakan cara dalam pengelolahan input yang nantinya menjadi ouput dalam penelitian ini. Pada proses ini menggunakan perancangan pada TOGAF ADM yang sesuai dengan batasan masalah dalam penelitian ini yaitu mulai dari preliminary phase, Architecture Vision, Business Architecture, Information System
Architecture yang terdiri dari Data Architecture dan Application Architecture, Technology Architecture, Opportunities and Solution dan migration planning. Pada gambar 1 menjelaskan metodologi penelitian.

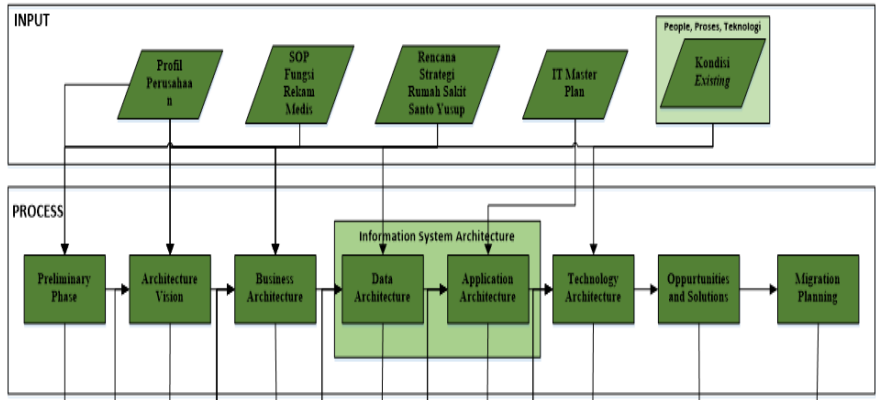

Gambar 1 Metodologi penelitian

Dan kajian output ini merupakanan hasil atau keluaran dari penelitian ini. Berikut Artifak yang dijelaskan pada setiap fase pada tabel II.

TABEL II

OUTPUT TOGAF ADM

\begin{tabular}{|c|c|}
\hline Fase & Output \\
\hline $\begin{array}{l}\text { Preliminary } \\
\text { Phase }\end{array}$ & Principle Catalog \\
\hline $\begin{array}{l}\text { Arhchitecture } \\
\text { Vision }\end{array}$ & $\begin{array}{l}\text { stakeholder Map Matrix, Value Chain Diagram, } \\
\text { Solution Concept Diagram, Goal Diagram, Goal } \\
\text { Catalog, dan Requirement Catalog. }\end{array}$ \\
\hline $\begin{array}{l}\text { Business } \\
\text { Arhchitecture }\end{array}$ & 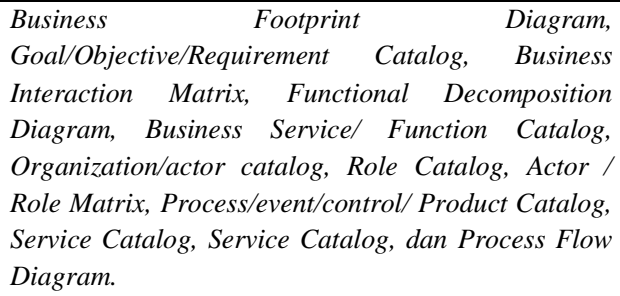 \\
\hline $\begin{array}{l}\text { Data } \\
\text { Arhchitecture }\end{array}$ & $\begin{array}{l}\text { Data Entity / Data Component Catalog, Data Entity / } \\
\text { Business Function Matrix, Application / Data Matrix, } \\
\text { Conceptual Data Diagram, Logical Data Diagram, } \\
\text { dan Data Dissemination Diagram. }\end{array}$ \\
\hline $\begin{array}{l}\text { Application } \\
\text { Arhchitecture }\end{array}$ & $\begin{array}{l}\text { application Portofolio Catalog, Application Interface } \\
\text { Catalog, Application/ Organization Matrix, } \\
\text { Application/ Function Matrix, Application/ Role } \\
\text { Matrix, Application Interaction Matrix, Application } \\
\text { Communication Diagram, Application And User } \\
\text { Location Diagram, dan Application Usecase } \\
\text { Diagram. }\end{array}$ \\
\hline $\begin{array}{l}\text { Technology } \\
\text { Arhchitecture }\end{array}$ & $\begin{array}{l}\text { Technology Standard Catalog, Technology Portofolio } \\
\text { Catalog, Application/Technology Matrix, } \\
\text { Environments and Locations Diagram, dan Platform } \\
\text { Decomposition Diagram }\end{array}$ \\
\hline $\begin{array}{l}\text { Opportunities } \\
\text { And Solutions }\end{array}$ & $\begin{array}{l}\text { Implementation Faktor Assessment and Deduction } \\
\text { Matrix, Consolidated Gaps, Solution, and } \\
\text { Dependencies Matrix, Consolidated and Reconcile } \\
\text { Interoperability Requirement, Project Context } \\
\text { Diagram, Benefit Diagram }\end{array}$ \\
\hline $\begin{array}{l}\text { Migration } \\
\text { Planning }\end{array}$ & $\begin{array}{l}\text { Value and Risk Assessment, Business Value } \\
\text { Assessment Diagram, Roadmap }\end{array}$ \\
\hline
\end{tabular}




\section{HASIL DAN ANALISIS}

\section{A. Preliminary Phase}

Preliminary phase menggambarkan tahapan dalam proses perancangan dengan melakukan penyusunan suatu framework dalam bentuk visi architecture dan juga prinsip - prinsip architecture berupa proses bisnis, data aplikasi dan teknologi. Preliminary phase memiliki artefak Principle Catalog yang berfungsi untuk mengetahui prinsip - prinsip umum di rumah sakit, yang dikaitkan dengan domain EA. Pada tabel III menjelaskan Principle Catalog rumah sakit.

TABEL III PRINCIPLE CATALOG

\begin{tabular}{|c|c|c|}
\hline $\mathrm{NO}$ & Arsitektur & Prinsip \\
\hline & \multirow{7}{*}{$\begin{array}{l}\text { Business } \\
\text { Architecture }\end{array}$} & Keselamatan dan kesembuhan pasien \\
\hline & & $\begin{array}{l}\text { Kesiapsediaan, keramah tamahan, dan } \\
\text { tanggung jawab }\end{array}$ \\
\hline & & Mutu pelayanan kesehatan \\
\hline & & Pendidikan kesehatan yang bermutu \\
\hline & & Kesejahteraan karyawan \\
\hline & & Kepatuhan hukum \\
\hline & & Mengandalkan harmonisasi kerja \\
\hline \multirow[t]{10}{*}{2} & \multirow[t]{10}{*}{ Data Achitecture } & Data adalah asset \\
\hline & & Data dapat diakses \\
\hline & & Sharing Data \\
\hline & & Data yang akurat \\
\hline & & Integrasi Data \\
\hline & & Backup database otomatis \\
\hline & & Pengelolaan data terpusat \\
\hline & & Keamanan data \\
\hline & & Upgrade data \\
\hline & & Data harus valid \\
\hline \multirow[t]{5}{*}{3} & \multirow{5}{*}{$\begin{array}{l}\text { Application } \\
\text { Architecture }\end{array}$} & Aplikasi mudah digunakan \\
\hline & & Hak akses aplikasi \\
\hline & & Integrasi aplikasi \\
\hline & & Upgrade aplikasi \\
\hline & & Fleksibilitas aplikasi \\
\hline \multirow[t]{7}{*}{4} & \multirow{7}{*}{$\begin{array}{l}\text { Technology } \\
\text { Architecture }\end{array}$} & Penggunaan teknologi yang real-time \\
\hline & & Interoperabilitas \\
\hline & & Keamanan infrastruktur teknologi \\
\hline & & Tata kelola infrastruktur teknologi \\
\hline & & Backup infrastruktur jaringan \\
\hline & & Availability \\
\hline & & Konektivitas server \\
\hline
\end{tabular}

\section{B. Architecture Vision}

Architecture Vision berfungsi untuk mengembangkan kapabilitas dan nilai bisnis pada level tertinggi perusahaan yang akan disampaikan sebagai hasil dari enterprise yang diusulkan dimanan fase ini akan menjelaskan tujuan dari objek penelitian pelayanan Rekam Medis rumah sakit. Architecture vision memiliki beberapa artefak diantarnya stakeholder map matrix, value chain, goal diagram \& goal catalog, solution concept diagram dan requirement catalog. Pada Gambar 2 adalah salah satu artefak pada Architetcure vision yaitu value chain diagram yang menggambarkan tujuan perusahaan yang dapat dilihat dari aktivitas - aktivitas utama dan pendukungknya.

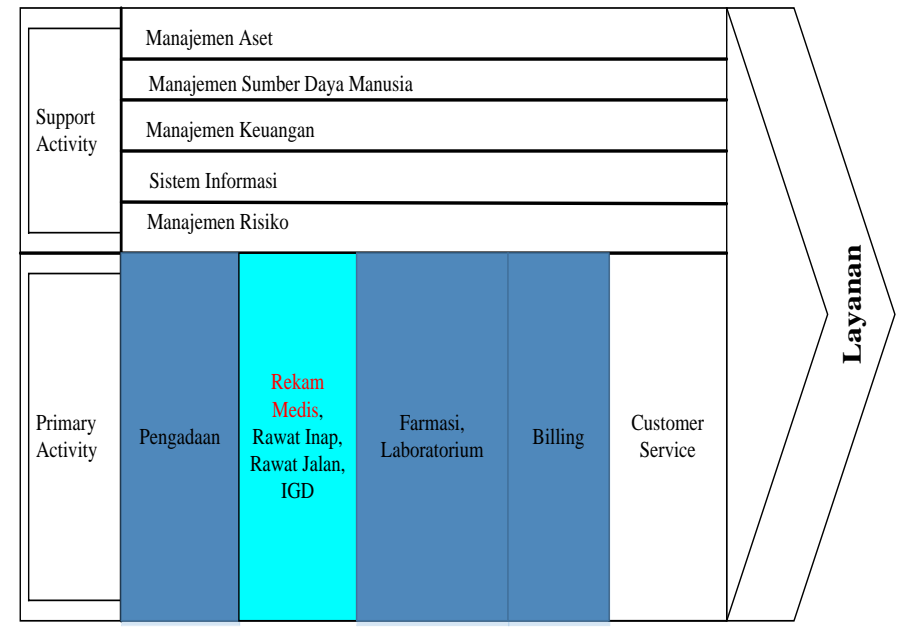

Gambar 2 Value chain

\section{Business Architecture}

Business Architecture mendeskripsikan bagaimana kebutuhan enterprise untuk mengoperasikan dan memenuhi bisnis goal, dan merespon driver strategis yang ditetapkan dalam arsitektur vision. Pada Fase bisnis arsitektur ini akan membahas tentang beberapa artefak yaitu Business Footprint Diagram, Goal/Objective/Requirement Catalog, Business Interaction Matrix, Functional Decomposition Diagram, Organization/actor catalog, Role Catalog, Actor role catalog, Process/event/control/ Product Catalog, Process Flow Diagram, Service Diagram, dan Business Function. Pada tabel IV dibawah ini menggambarkan salah satu artefak pada Business Architecture yaitu Proses Catalog dengan memetakan antara organizational process dan service.

TABEL IV

PROCESS CATALOG

\begin{tabular}{|l|l|}
\hline ORGANIZATIONAL PROCESS & SERVICE \\
\hline Pengisian Rekam Medis & \multirow{2}{*}{$\begin{array}{l}\text { Pengelolaan dan } \\
\text { Analisis Data }\end{array}$} \\
\cline { 1 - 1 } Pengembalian Rm Rj Dan Igd & \multirow{2}{*}{ Pelaporan Rm } \\
\cline { 1 - 1 } Penentuan Dan Pemberian Kodetifikasi & \\
\cline { 1 - 1 } Pengumpulan Data Pelaporan & Pengadaan \\
Analisa Rm & Rekam Medis \\
\hline Retensi Rm & \multirow{2}{*}{ Trace RM } \\
\cline { 1 - 1 } Pengadaan Bhp Rekam Medis & \\
\hline Pengadaan Barang Jasa Rekam Medis & \\
\cline { 1 - 1 } Peminjaman dan Pengambilan berkas RM & \\
\cline { 1 - 1 } Pembuatan visum et repertum &
\end{tabular}

Pada tabel V menggambarkan service catalog, dimana pada service catalog ini tidak memerlukan layanan berkas RM untuk melakukan pengisian RM pasien hingga pembuatan permintaan visum et repertum. 
TABEL V

PROCESS CATALOG

\begin{tabular}{|c|c|}
\hline SERVICE & UIREMENT \\
\hline $\begin{array}{l}\text { Pengelolaan } \\
\text { dan data } \\
\text { analisis }\end{array}$ & $\begin{array}{l}\text { a. Ketersediaan system yang memudahkan } \\
\text { pelayanan terhadap pasien } \\
\text { b. Response time penyediaan dokumen RJ dalam } \\
\text { waktu } 10 \text { menit tercapai sebesar } 90 \% \text { dan } \\
\text { doukumen RI dalam waktu } 15 \text { menit tercapai } \\
\text { sebesar 90\% } \\
\text { c. Response time berkas RM RJ saat dibutuhkan } \\
\text { terpenuhi 100\% dan berkas RM RI 70\% } \\
\text { d. Kelengkapan pengisian RM dalam waktu } 2 \times 24 \\
\text { jam yang dapat tercapai } 60 \% \\
\text { e. Adanya Pelatihan kodetifikasi \& INA CBG'S } \\
\text { f. Adanya pelatihan manajemen RM serta kegiatan } \\
\text { pormiki } \\
\text { g. Menerapkan kegiatan Exhouse Training PDE } \\
\text { seperti kegiatan seminar yang bertemakan } \\
\text { diskusi nasional tentang Morbidity Coding } \\
\text { h. Adanya tempat layanan yang terfokus untuk } \\
\text { pendaftaran pasien RJ }\end{array}$ \\
\hline $\begin{array}{l}\text { Pelaporan } \\
\text { RM }\end{array}$ & $\begin{array}{l}\text { a. Tersedianya pelaporan RS yang sesuai dengan } \\
\text { peraturan atau Standar RM } \\
\text { b. Penyeleseian korespodensi rekam medis } 80 \% \\
\text { selesai dalam waktu 1-3 hari } \\
\text { c. Menerapkan berkas RM yang sudah tidak aktif, } \\
\text { d. Menerapkan pemusnahan berkas RM } 5 \text { tahun } \\
\text { sekali } \\
\text { e. Tersedianya pelaporan RS yang sesuai dengan } \\
\text { peraturan atau Standar RM }\end{array}$ \\
\hline $\begin{array}{l}\text { Pengadaan } \\
\text { Rekam } \\
\text { Medis }\end{array}$ & $\begin{array}{l}\text { a. Adanya pelatihan dan pengembangan } \\
\text { kemampuan karyawan sesuai kebutuhan yang } \\
\text { disesuaikan dengan RKA RM } \\
\text { b. Tersedianya pelatihan online mengenai RM bagi } \\
\text { karyawan } \\
\text { c. Tersedianya materi-pelatihan sesuai dengan } \\
\text { aturan RM RS } \\
\text { d. Adanya pembinaan staff yang memiliki pola } \\
\text { kerja sistematis } \\
\text { e. Adanya pembinaan staff untuk menjalankan } \\
\text { kegiatan managerial pada RM RS } \\
\text { f. Dokumentasi standar akreditasi mengenai beban } \\
\text { kerja untuk pelaksanaan RM } \\
\text { g. Adanya pemanfaatan anggaran rutin, anggaran } \\
\text { Opex dan capex }\end{array}$ \\
\hline Trace RM & $\begin{array}{l}\text { a. Peminjaman berkas RM sesuai dengan tata } \\
\text { aturan peminjaman RS } \\
\text { b. Penyeleseian korespodensi rekam medis } 80 \% \\
\text { selesai dalam waktu 1-3 hari ketersediaan sisten } \\
\text { yang memudahkan pelayanan terhadap pasien }\end{array}$ \\
\hline
\end{tabular}

\section{Data Architecture}

Data architecture berfungsi untuk mengelola data yang terdapat diperusahaan. Data architecture memiliki beberapa artefak yaitu data entity/ data component catalog, data entity atau business function matrix, entity relation Diagram, application / data matrix, data dissemination diagram dan data architecture evaluation. Berikut adalah gambar 3 gambar 6 salah satu artefak data architecture yaitu Data Dissemination Diagram menunjukkan hubungan antara entitas data, layanan bisnis, dan komponen aplikasi yang memiliki hubungan dengan aplikasi apa dan data apa saja yang digunakan.

Pada Gambar 3 ini merupakan Data Dissemination Diagram Pengelolaan dan Analisis Data yang terintegrasi dengan program Rekam Medis, program keuangan, program farmasi dan program HIS to LIS. Pada Gambar 4 ini merupakan Data Dissemination Diagram Pelaporan RM yang terintegrasi dengan program Rekam Medis, dan program pengelolaan Laporan. Pada Gambar 5 ini merupakan Data Dissemination Diagram Pengadaan RM yang terintegrasi dengan program Rekam Medis, dan program Logistik. Pada Gambar 6 ini merupakan Data Dissemination Diagram Trace RM yang terintegrasi dengan program Rekam Medis, dan program HIS to LIS. 


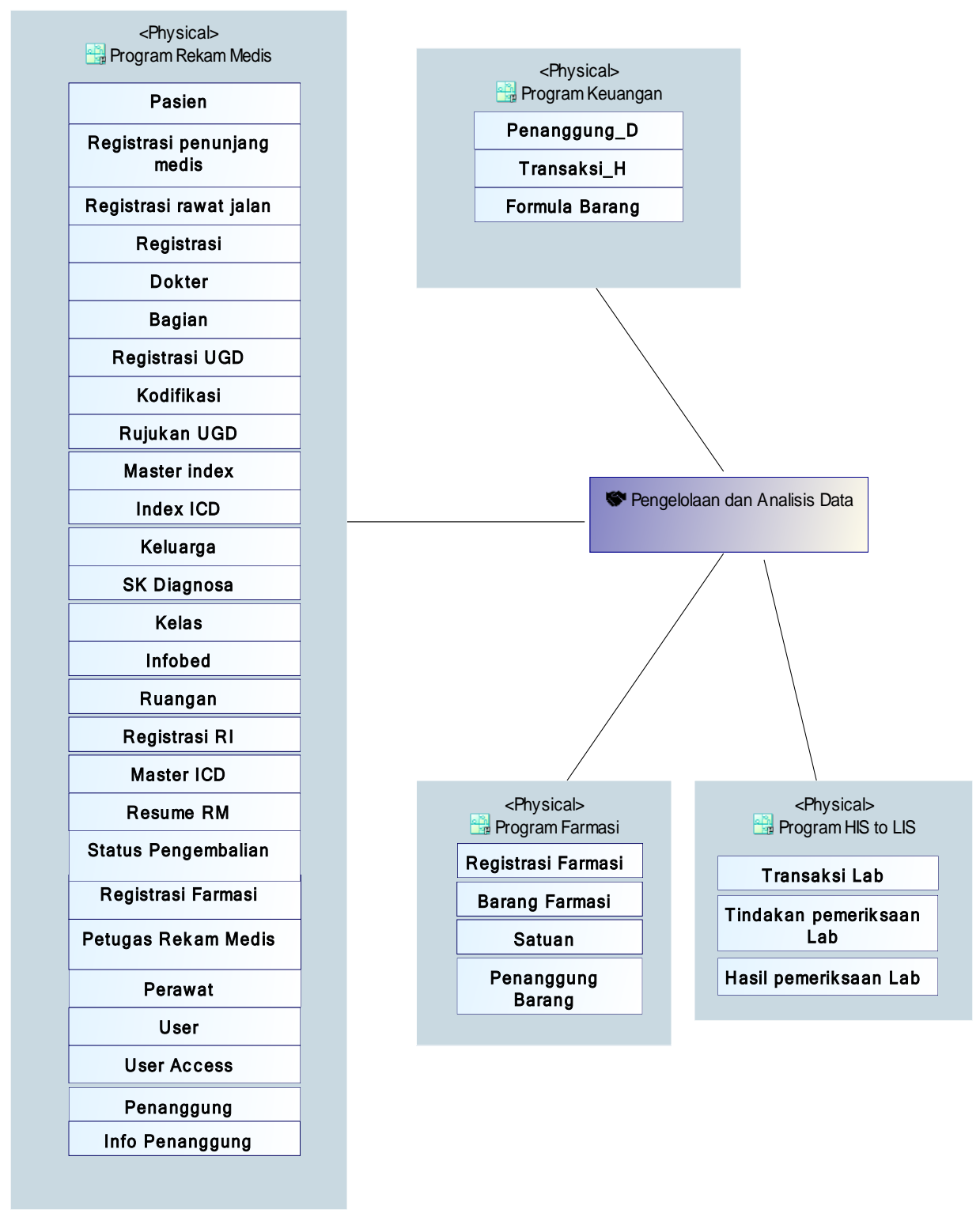

Gambar 3 Data dissemination diagram pengelolaan dan analisis data

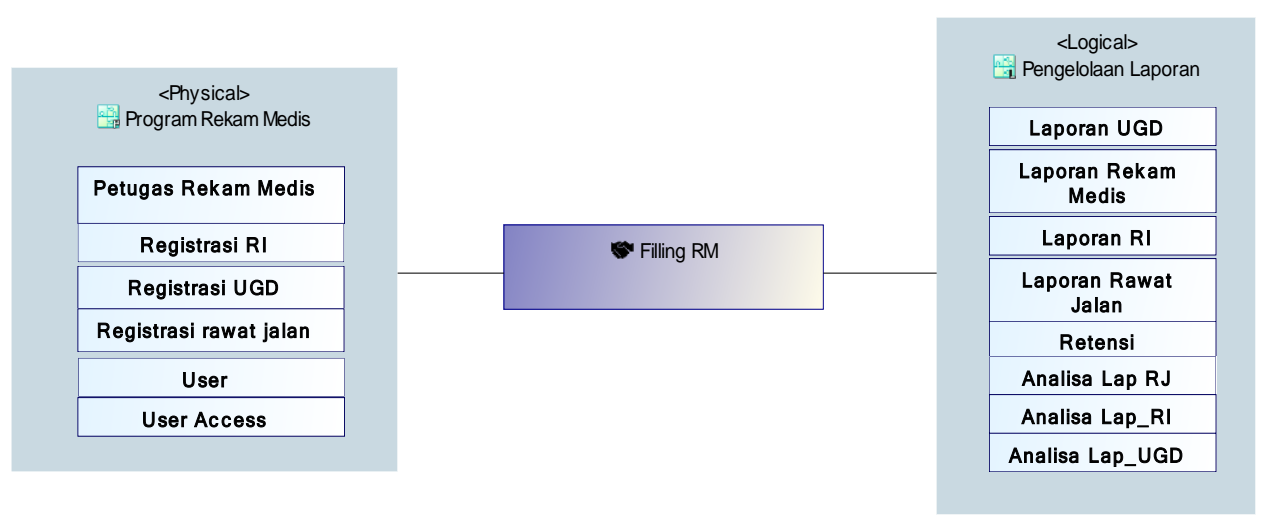

Gambar 4 Data dissemination diagram pelaporan RM 


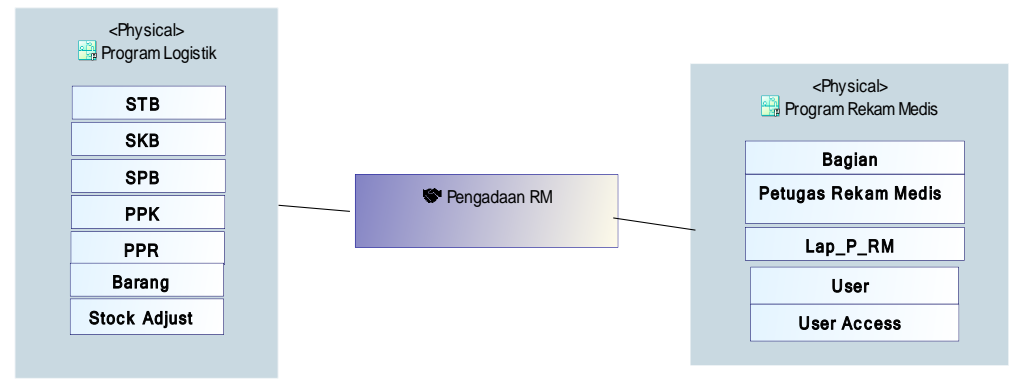

Gambar 5 Data dissemination diagram pengadaan RM

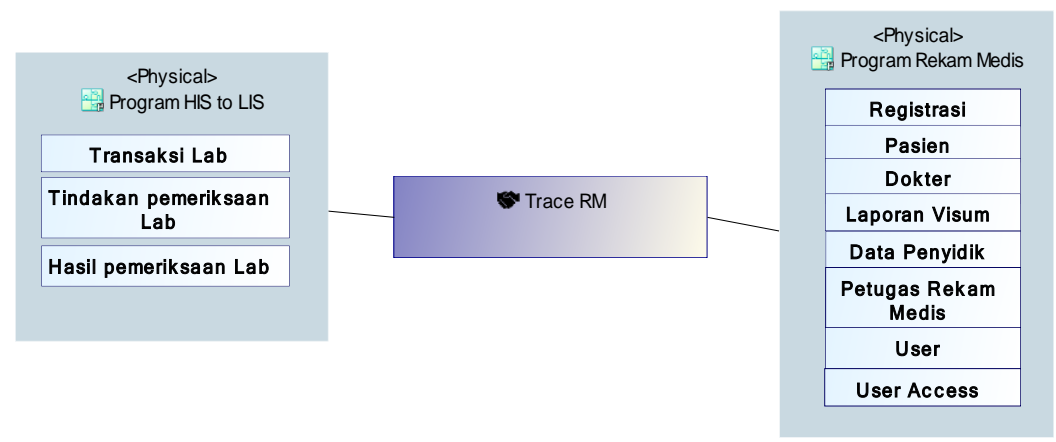

Gambar 6 Data dissemination diagram trace RM

\section{E. Application Architecture}

Application architecture menjelaskan jenis aplikasi yang akan dibutuhkan untuk menunjang pemprosesan data dan mendukung jalannya bisnis pada perusahaan. Beberapa artefak yang dihasilkan adalah application/ organization matrix, application/ function matrix, application interaction matrix, application communication diagram, application usecase diagram. Logical application fungsi Rekam Medis di realisasikan dalam physical application portal I-HOSST. IHOSST (Integrated Hospital Information System) merupakan sebuah physical application target untuk menunjang semua fungsi rumah sakit yang menjadi objek penelitian ini, dengan mengintegrasikan antara semua database pada setiap aplikasi rumah sakit. Pada gambar 7 menggambarkan application communication diagram dari Pengelolaan dan Analisis Data yang berhubungan dengan trace RM, pengadaan RM, dan filling RM. sedangkan Filling RM berhubungan dengan pengelolaan dan analisis data. Pengadaan RM berhubungan dengan filling RM. Trace RM dan pengelolaan dan analisis data.

Berikut adalah gambar 7 salah satu artefak application architecture yaitu Application Communication Diagram yang menggambarkan seluruh model dan pemetaan terkait dengan komunikasi antara aplikasi dengan menunjukkan keterkaitan antara komponen logical.

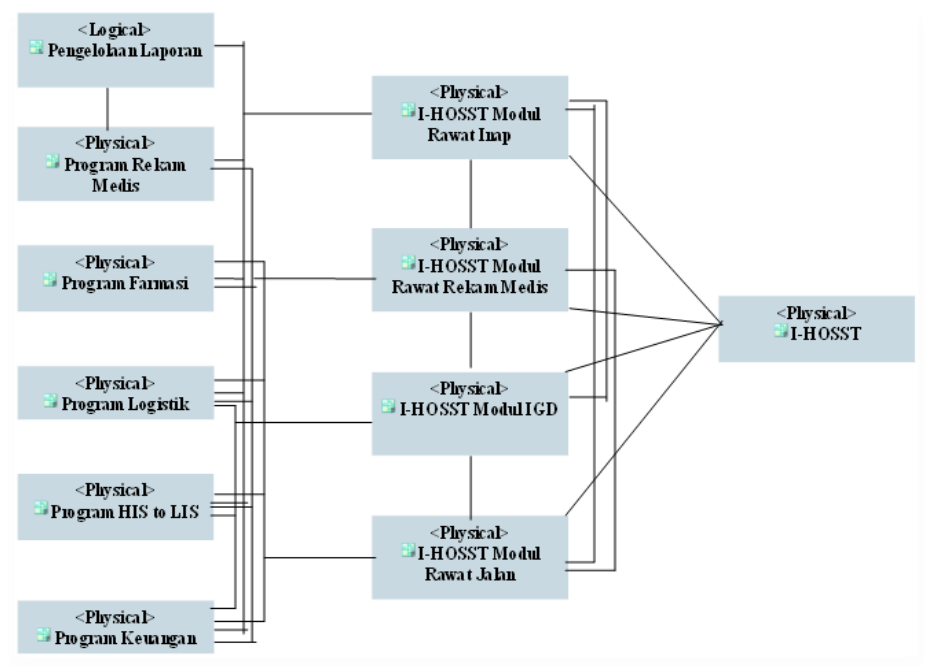

Gambar 7 Application communication diagram 


\section{F. Technology Architecture}

Technology architecture bertujuan untuk membangun arsitektur teknolgi sesuai dengan requirement yang ada dengan menggambarkan software, hardware dan jaringan infrastruktur yang dibutuhkan dan juga mengidentifikasi infrastruktur teknologi informasi yang ada. Technology Architecture menghasilkan beberapa artifak, yaitu technology standards catalog, technology portfolio catalog, application / technology matrix, environments and locations diagram dan platform decomposition diagram. Pada gambar 8 adalah salah satu artefak technology architecture yaitu Environment and Location Diagram yang mengidentifikasi technology / aplikasi apa saja yang digunakan, dan lokasi pengguna bisnis yang berinteraksi dengan aplikasi serta hubungan antar komponennya.

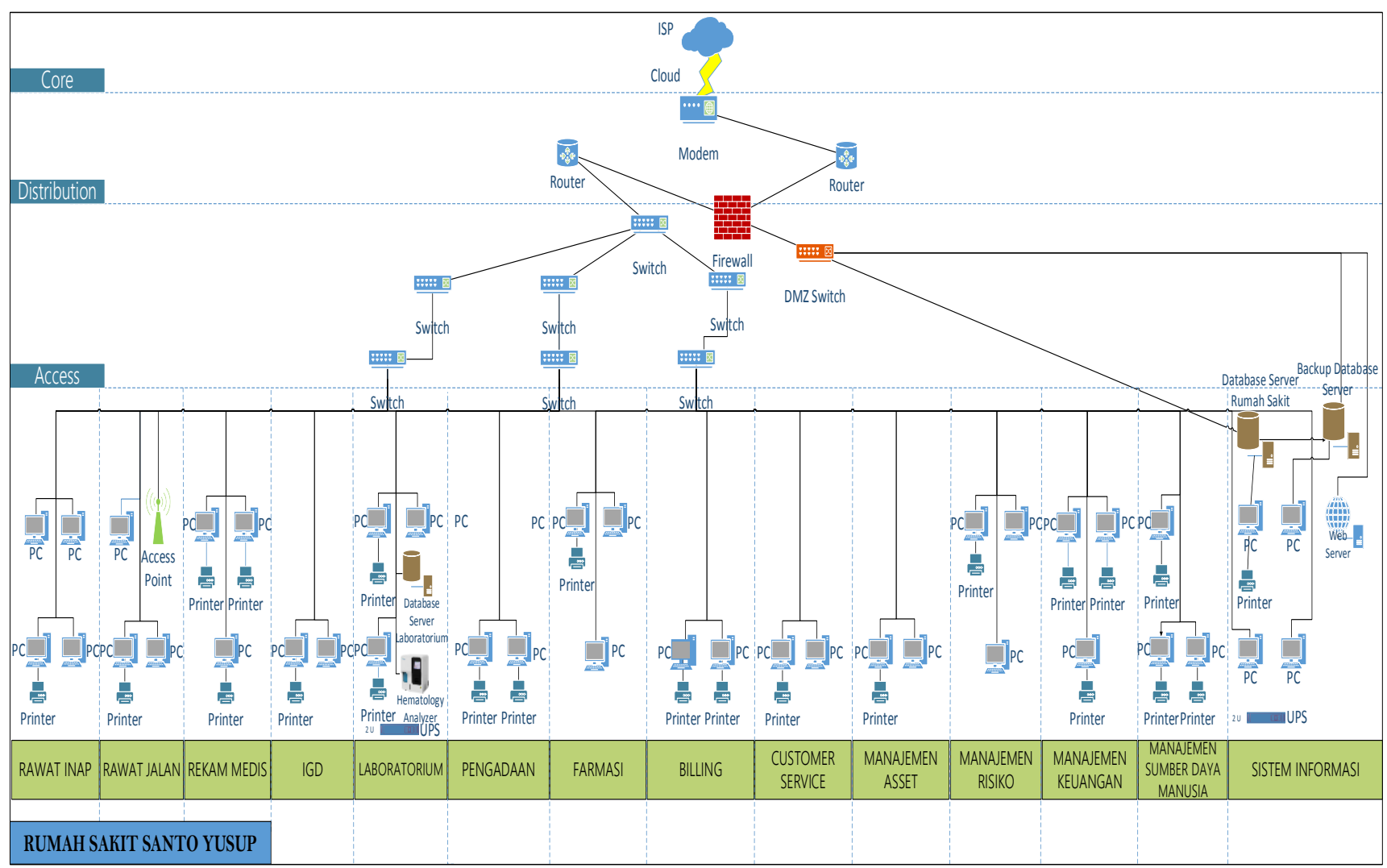

Gambar 8 Environment and location diagram

\section{G. Opportunities and Solution}

Opportunities and Solutions digunakan untuk mengevaluasi model yang dibangun sehingga dapat mencapai sasaran rancangan arsitektur. Pada Oppourtunity and solution terdapat beberapa artefak diantaranya implementation factor assessment and deducation, consolidated gaps, solutions, and dependencies, project context diagram, benefit diagram dan inter- system interoperability. Pada tabel VI dibawah ini akan menggambarkan salah satu artefak opportunity and solution yaitu Implementation Factor Assesment and Deducation dengan memetakan 5 factor yaitu Risk, issue, dependencies, assumptions, actions dan impacts.

TABEL VI

IMPLEMENTATION FACTOR ASSESMENT AND DEDUCATION

\begin{tabular}{|c|c|l|l|}
\hline \multicolumn{4}{|c|}{ Implementation Factor Assessment and Deduction Matrix } \\
\hline Factor & Keterangan & Description & \multicolumn{2}{c|}{ Deduction } \\
\hline Risk & Bencana alam & $\begin{array}{l}\text { Bencana alam } \\
\text { yang }\end{array}$ & $\begin{array}{l}\text { Dengan adanya } \\
\text { server backup }\end{array}$ \\
\hline
\end{tabular}

\begin{tabular}{|c|c|c|c|}
\hline \multicolumn{4}{|c|}{ Implementation Factor Assessment and Deduction Matrix } \\
\hline Factor & Keterangan & Description & Deduction \\
\hline & & $\begin{array}{l}\text { mungkin } \\
\text { terjadi seperti } \\
\text { banjir, gempa } \\
\text { bumi, dan } \\
\text { angin puting } \\
\text { beliung yang } \\
\text { dapat } \\
\text { menyebabkan } \\
\text { kerusakan } \\
\text { sistem. }\end{array}$ & $\begin{array}{l}\text { data dan aplikasi } \\
\text { memungkinkan } \\
\text { data dapat terjaga } \\
\text { dengan aman } \\
\text { pada lokasi yang } \\
\text { berbeda. }\end{array}$ \\
\hline & Human Error & $\begin{array}{l}\text { Human error } \\
\text { yang } \\
\text { mungkin } \\
\text { terjadi adalah } \\
\text { kebakaran, } \\
\text { kesalahan } \\
\text { teknis, dan } \\
\text { lain } \\
\text { sebagainya } \\
\text { yang dapat }\end{array}$ & $\begin{array}{l}\text {-Adanya server } \\
\text { backup untuk } \\
\text { backup data dan } \\
\text { aplikasi. } \\
\text {-Adanya } \\
\text { pelatihan } \\
\text { peningkatan skill } \\
\text { sehingga } \\
\text { kesalahan akan } \\
\text { diminimalisir }\end{array}$ \\
\hline
\end{tabular}




\begin{tabular}{|c|c|c|c|}
\hline \multicolumn{4}{|c|}{ Implementation Factor Assessment and Deduction Matrix } \\
\hline Factor & Keterangan & Description & Deduction \\
\hline & & $\begin{array}{l}\text { menyebabkan } \\
\text { kerugian bagi } \\
\text { rumah sakit }\end{array}$ & \\
\hline Issue & $\begin{array}{l}\text { Penggunaan } \\
\text { aplikasi portal }\end{array}$ & $\begin{array}{l}\text { Penggunaan } \\
\text { apllikasi } \\
\text { portal sebagai } \\
\text { aplikasi yang } \\
\text { terintegrasi } \\
\text { dengan } \\
\text { layanan } \\
\text { rumah sakit }\end{array}$ & $\begin{array}{l}\text {-Adanya } \\
\text { penambahan } \\
\text { infrastruktur. } \\
\text {-Adanya } \\
\text { sosialisasi } \\
\text { penggunaan } \\
\text { aplikasi portal }\end{array}$ \\
\hline Dependencies & $\begin{array}{l}\text { Ketergantungan } \\
\text { data pasien dan } \\
\text { rekam medis }\end{array}$ & $\begin{array}{l}\text { Segala proses } \\
\text { pelayanan } \\
\text { membutuhkan } \\
\text { data pasien } \\
\text { untuk } \\
\text { menunjang } \\
\text { keakuratan } \\
\text { data rekam } \\
\text { medis. }\end{array}$ & $\begin{array}{l}\text {-Adanya aplikasi } \\
\text { I-HOSST yang } \\
\text { mengintegrasikan } \\
\text { aplikasi-aplikasi } \\
\text { pada rumah sakit } \\
\text {-Berjalannya } \\
\text { infrastruktur } \\
\text { yang baik untuk } \\
\text { menunjang } \\
\text { kelancaran } \\
\text { komunikasi data } \\
\text { dan pelayanan }\end{array}$ \\
\hline Assumptions & $\begin{array}{l}\text { Pemahaman } \\
\text { pegawai } \\
\text { terhadap sistem } \\
\text { informasi I- } \\
\text { HOSST }\end{array}$ & $\begin{array}{l}\text { Aplikasi } \\
\text { portal I- } \\
\text { HOSST } \\
\text { sebagai } \\
\text { aplikasi } \\
\text { terintegrasi } \\
\text { untuk } \\
\text { mendukung } \\
\text { pelayanan } \\
\text { rumah sakit. }\end{array}$ & $\begin{array}{l}\text {-Adanya } \\
\text { sosialisasi } \\
\text { terhadap } \\
\text { penggunaan } \\
\text { aplikasi. } \\
\text {-Adanya manual } \\
\text { book untuk setiap } \\
\text { user yang } \\
\text { membutuhkan, }\end{array}$ \\
\hline Actions & $\begin{array}{l}\text { Perbedaan } \\
\text { identitas pasien }\end{array}$ & $\begin{array}{l}\text { Identitas } \\
\text { pasien yang } \\
\text { tidak sesuai } \\
\text { dengan } \\
\text { catatan rekam } \\
\text { medis. }\end{array}$ & $\begin{array}{l}\text { Adanya aturan } \\
\text { untuk } \\
\text { menggunakan } \\
\text { identitas yang } \\
\text { diakui oleh } \\
\text { pemerintah. }\end{array}$ \\
\hline Impacts & $\begin{array}{l}\text { Implementasi } \\
\text { sistem } \\
\text { informasi } \\
\text { HOOST }\end{array}$ & $\begin{array}{l}\text { Implementasi } \\
\text { sistem } \\
\text { informasi I- } \\
\text { HOSST } \\
\text { sebagai } \\
\text { aplikasi }\end{array}$ & $\begin{array}{l}\text {-Adanya } \\
\text { pemeliharaan } \\
\text { infrastruktur agar } \\
\text { layanan dapat } \\
\text { terus berjalan. }\end{array}$ \\
\hline
\end{tabular}

\section{H. Migration Planning}

Migration planning memiliki beberapa artefak diantaranya Estimasi value dan risk, business value assessment, prioritas pembangunan proyek dan IT Radmap Final. Dalam menentukan estimasi value dan risk dilakukan dengan menggunakan kuisioner business value assessment kepada pihak SISFO rumah sakit yang dapat dilihat pada tabel VII dibawah ini.

TABEL VII

ESTIMASI VALUE DAN RISK PROYEK

\begin{tabular}{|c|l|c|c|}
\hline NO & \multicolumn{1}{|c|}{ SOLUSI } & $\begin{array}{c}\text { ESTIMASI } \\
\text { VALUE }\end{array}$ & $\begin{array}{c}\text { ESTIMASI } \\
\text { RISK }\end{array}$ \\
\hline 1 & I-HOSST Modul Rekam Medis & 4 & 3 \\
\hline 2 & I-HOSST Modul Rawat Jalan & 3 & 4 \\
\hline 3 & I-HOSST Modul Rawat Inap & 3 & 4 \\
\hline 4 & $\begin{array}{l}\text { I-HOSST Modul Instalasi Gawat } \\
\text { Darurat (IGD) }\end{array}$ & 4 & 3 \\
\hline 5 & Pengembangan Infrastruktur & 4 & 4 \\
\hline
\end{tabular}

Gambar 9 dibawah menggambarkan business value assessment dengan memberikan kuisioner kepada pihak rumah sakit terhadap tanggapan aplikasi dan infrastruktur yang diusulkan.

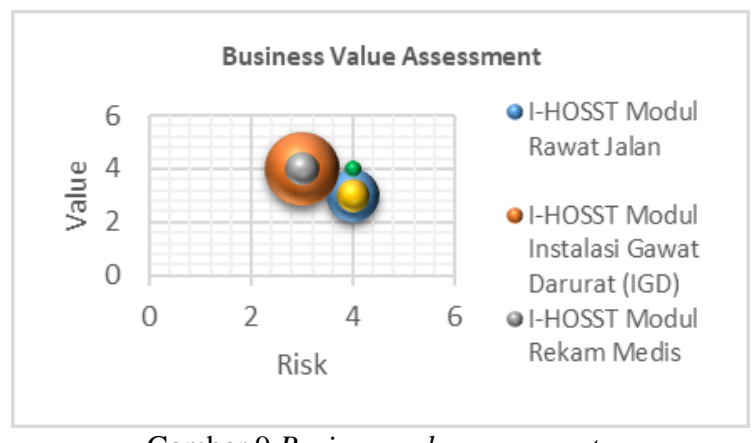

Gambar 9 Business value assesment

Berdasarkan gambar 9 Business Value Assesment dapat membantu dalam menentukan prioritas pembangunan proyek yang digunakan untuk menentukan urutan proyek - proyek yang dibangun berdasarkan prioritasnya. Dalam menentukan prioritas pembangunan proyek ditentukan berdasarkan value tertinggi dengan risk terendah. Pada tabel VIII menggambarkan prioritas pembangunan proyek IT rumah sakit.

TABEL VIII

PRIORITAS PEMBANGUNAN PROYEK

\begin{tabular}{|c|l|c|}
\hline No & \multicolumn{1}{|c|}{ Solusi } & $\begin{array}{l}\text { Urutan } \\
\text { Prioritas }\end{array}$ \\
\hline 1 & Pengembangan Infrastruktur & 1 \\
\hline 2 & I-HOSST Modul Rekam Medis & 2 \\
\hline 3 & $\begin{array}{l}\text { I-HOSST Modul Instalasi Gawat Darurat } \\
\text { (IGD) }\end{array}$ & 3 \\
\hline 4 & I-HOSST Modul Rawat Jalan & 4 \\
\hline 5 & I-HOSST Modul Rawat Inap & 5 \\
\hline
\end{tabular}

I. Validasi Perancangan Enterprise Architecture

Berdasarkan pada tabel IX adalah pengukuran hasil Feedback berdasarkan studi kasus diatas sebagai berikut:

TABEL IX

PENGIKURAN HASIL FEEDBACK

\begin{tabular}{|c|c|c|c|c|c|}
\hline \multirow{2}{*}{ Pertanyaan } & \multicolumn{4}{|c|}{ Nilai } & \multirow{2}{*}{$\begin{array}{c}\text { Persentase } \\
\text { (Nilai X 20\%) }\end{array}$} \\
\hline & 1 & 3 & 4 & 5 & \\
\hline \multicolumn{6}{|c|}{ Business Architecture } \\
\hline $\begin{array}{l}\text { Proses bisnis usulan } \\
\text { sesuai dengan kebutuhan } \\
\text { bisnis Rekam Medis }\end{array}$ & & & & $\mathrm{V}$ & $100 \%$ \\
\hline $\begin{array}{l}\text { Proses bisnis usulan } \\
\text { mendukung pencapaian } \\
\text { goal Rekam Medis }\end{array}$ & & & & $\mathrm{V}$ & $100 \%$ \\
\hline \multicolumn{6}{|c|}{ Data Architecture } \\
\hline $\begin{array}{l}\text { Kesesuaian entitas data } \\
\text { usulan dengan } \\
\text { kebutuhan data terhadap } \\
\text { proses bisnis usulan } \\
\text { Rekam Medis }\end{array}$ & & & & $\mathrm{V}$ & $100 \%$ \\
\hline \multicolumn{6}{|c|}{ Application Architecture } \\
\hline $\begin{array}{l}\text { Aplikasi usulan dapat } \\
\text { mendukung kegiatan } \\
\text { operasional Rumah }\end{array}$ & & & & $\mathrm{V}$ & $100 \%$ \\
\hline
\end{tabular}




\begin{tabular}{|l|l|l|l|l|l|l|}
\hline \multicolumn{1}{|c|}{ Pertanyaan } & \multicolumn{3}{c|}{ Nilai } & Persentase \\
\hline Sakit. & & & & & & \\
\hline $\begin{array}{l}\text { Aplikasi usulan dapat } \\
\text { beroperasi pada berbagai } \\
\text { platform teknologi }\end{array}$ & & & & & V & $100 \%$ \\
\hline \multicolumn{2}{|c|}{ Technology Architecture } & & \\
\hline $\begin{array}{l}\text { Teknologi usulan dapat } \\
\text { menanggapi perubahan } \\
\text { kebutuhan bisnis }\end{array}$ & & & & $\mathrm{V}$ & $100 \%$ \\
\hline $\begin{array}{l}\text { Teknologi usulan dapat } \\
\text { mendukung kinerja } \\
\text { aplikasi }\end{array}$ & & & & $\mathrm{V}$ & \\
\hline $\begin{array}{l}\text { Total Nilai Persentase } \\
\text { (Jumlah persentase / } \\
\text { Jumlah Pertanyaan) }\end{array}$ & \multicolumn{2}{|c|}{35} & & $100 \%$ \\
\hline
\end{tabular}

Pada tabel X menggambarkan Feedback Target Architecture dengan menggambarkan usulan yang diberikan dari pihak Rumah Sakit

TABEL $X$

FEEDBACK TARGET ARCHITECTURE

\begin{tabular}{|c|c|}
\hline Pertanyaan & Feedback \\
\hline \multicolumn{2}{|c|}{ Business Architecture } \\
\hline $\begin{array}{l}\text { Proses bisnis usulan sesuai } \\
\text { dengan kebutuhan bisnis Rekam } \\
\text { Medis }\end{array}$ & $\begin{array}{l}\text { Perlu di perdalam dari jenis laporan } \\
\text { Rekam Medis dan pengembangan } \\
\text { fungsi lain }\end{array}$ \\
\hline $\begin{array}{l}\text { Proses bisnis usulan mendukung } \\
\text { pencapaian goal Rekam Medis }\end{array}$ & \begin{tabular}{lcr}
\multicolumn{3}{l}{ Aplikasi yang diusulkan (disediakan) } \\
sudah mendukung & goal & Rekam \\
Medis, namun & masih & sulit \\
diimplementasikan & & karena \\
memerlukan pertimbangan dari RS
\end{tabular} \\
\hline \multicolumn{2}{|c|}{ Data Architecture } \\
\hline $\begin{array}{l}\text { Kesesuaian entitas data usulan } \\
\text { dengan kebutuhan data terhadap } \\
\text { proses bisnis usulan Rekam } \\
\text { Medis }\end{array}$ & $\begin{array}{l}\text { Data usulan sudah hampir mencakup } \\
\text { kebutuhan data secara keseluruhan }\end{array}$ \\
\hline \multicolumn{2}{|c|}{ Application Architecture } \\
\hline $\begin{array}{l}\text { Aplikasi usulan dapat mendukung } \\
\text { kegiatan operasional Rumah } \\
\text { Sakit. }\end{array}$ & $\begin{array}{l}\text { Aplikasi usulan yang diberikan } \\
\text { secara garis besar dapat mendukung } \\
\text { kegiatan operasional Rumah Sakit }\end{array}$ \\
\hline $\begin{array}{l}\text { Aplikasi usulan dapat beroperasi } \\
\text { pada berbagai platform teknologi }\end{array}$ & $\begin{array}{l}\text { Aplikasi usulan yang diberikan dapat } \\
\text { mendukung pada berbagai platform } \\
\text { teknologi }\end{array}$ \\
\hline \multicolumn{2}{|c|}{ Technology Architecture } \\
\hline $\begin{array}{l}\text { Teknologi usulan dapat } \\
\text { menanggapi perubahan kebutuhan } \\
\text { bisnis }\end{array}$ & $\begin{array}{l}\text { Technology usulan yang diberikan } \\
\text { mampu menanggapi perubahan } \\
\text { kebutuhan bisnis kedepan setidaknya } \\
\text { selama } 5 \text { tahun. }\end{array}$ \\
\hline $\begin{array}{l}\text { Teknologi usulan dapat } \\
\text { mendukung kinerja aplikasi }\end{array}$ & $\begin{array}{l}\text { Technologi } \text { usulan mampu } \\
\text { mendukung dengan baik untuk } \\
\text { kinerja aplikasi yang sudah ada dan } \\
\text { yang diusulkan. }\end{array}$ \\
\hline
\end{tabular}

\section{KESIMPULAN}

Kajian ini dilakukan di rumah sakit khusunya pada fungsi Rekam Medis, dengan melakukan perancangan Enterprise Architecture menggunakan metode TOGAF ADM dari preliminary phase hingga migration planning. Berdasarkan hasil analisis arsitektur model pada kajian ini diusulkan sebuah aplikasi I-HOSST dengan mengintegrasikan seluruh layanan pada rumah sakit, sehingga dengan adanya aplikasi ini proses bisnis dirumah sakit akan terintegrasi dan berjalan lebih efektif dan efisien. Selain pada teknologi arsitektur mengusulkan infrastruktur teknologi untuk mendukung berjalannya aplikasi seperti adanya Cloud server berfungsi sebagai backup recovery saat server utama mengalami gangguan.

\section{DAFTAR PUSTAKA}

[1] Prisyanti, Prasetyo \& Mulyana, n.d, "Perancangan Arsitetktur Bisnis dan Arsitektur Data untuk Layanan Jasa Keuangan PT.XYZ menggunakan TOGAF ADM".

[2] Purnawan, D. A., dan Surendro, K. "Building Enterprise Architecture for Hospital Information System," dalam Fourth International Conference on Information and Communication Technologies, Bandung, 2016.

[3] Ahsan, K., Shah, H., and Kingston, P. "HEALTHCARE MODELLING THROUGH ENTERPRISE," Seventh International Conference on Information Technology, p. 6, 2010.

[4] Winter, R., and Schelp, J. "Enterprise architecture governance: the need for a business-to-IT approach," ACM symposium on Applied computing, Fortaleza, Ceara, Brazil,, pp. 548-552, 2008.

[5] Menteri Kesehatan Republik Indonesia, "PERATURAN MENTERI KESEHATAN REPUBLIK INDONESIA TENTANG REKAM MEDIS," Menteri Kesehatan, Jakarta, 2008.

[6] Zachman, J. A. "A Framework for Information Systems Architecture," IBM Systems Journal, vol. 26, no. 3, 1987.

[7] Gundars, O. "Definition of Enterprise Architecture Centric Models for the System Engineer," TASC, p. 8, 2001.

[8] Muhamad, C. F., and Bandung, Y. (2016) "Designing an Enterprise Architecture Government Organization Based On TOGAF ADM and SONA," International Conference on Information Technology Systems and Innovation (ICITSI), p. 6.

[9] Group, T.O. "The Open Group Architecture Framework (TOGAF 9.1).u.s.," 2011. 